\title{
Anxiety in adult foreign language learning: The case of Ghanaian undergraduate students of Spanish
}

\author{
Benedicta Adokarley Lomotey \\ Senior Lecturer \\ University of Ghana \\ Modern Languages Department (Spanish) \\ Legon-Accra \\ Email: balomotey@ug.edu.gh
}

Submitted: February 27, 2021/ Accepted: June 17, 2021/ Published: August 27, 2021

\begin{abstract}
This study investigates students' anxiety levels through the administration of the Foreign Language Classroom Anxiety Scale (FLCAS) among Spanish learners at a Ghanaian University. The differences according to level of instruction, the association between classroom anxiety and performance, as well as the possible relationship between language immersion and anxiety are also analysed using descriptive statistics, and Pearson's Moment Correlation Coefficient. The findings indicate that the majority of student participants experienced foreign language classroom anxiety. Nonetheless, contrary to previous research findings, anxiety was not found to decrease systematically as proficiency increased. Additionally, as confirmed by previous studies, the result of the Pearson correlation analysis showed that students' overall Spanish classroom anxiety and their classroom achievement had a negative association.
\end{abstract}

Keywords: Foreign Language Classroom Anxiety, academic performance, Spanish, language immersion, Ghana

\section{Resumen}

Este estudio investiga los niveles de ansiedad de los estudiantes a través de la administración de la Escala de Ansiedad de Aula de Lengua Extranjera (FLCAS) entre los estudiantes de español en una Universidad de Ghana. Las 
diferencias según el nivel de instrucción, la asociación entre la ansiedad y el rendimiento en el aula, así como la posible relación entre la inmersión y la ansiedad en el lenguaje también se analizan utilizando estadísticas descriptivas, y el coeficiente de correlación de momento de Pearson. Los resultados indican que la mayoría de los estudiantes participantes experimentaron ansiedad en el aula de idiomas extranjeros. No obstante, contrariamente a los resultados de investigaciones anteriores, no se observó que la ansiedad disminuyera sistemáticamente a medida que aumentaba la competencia. Además, como confirman estudios anteriores, el resultado del análisis de correlación de Pearson mostró que la ansiedad general de los estudiantes en el aula de español y sus logros en el aula tenían una asociación negativa.

Palabras Clave: Ansiedad en el aula de lengua extranjera, rendimiento académico, español, inmersión lingüística, Ghana

\section{Introduction}

The language classroom setting is one of complex relationships where different factors come into play and affect the students' learning of the second language. These factors range from pedagogical features (e.g., course design, teaching methodology) to personal learner characteristics (e.g., introversion/ extroversion) and psychological undercurrents. An aspect of psychological dynamics that has caught the attention of language scholars since the 1970s is foreign language anxiety (Dewaele, Magdalena, \& Saito, 2019).

Horwitz, Horwitz and Cope describe foreign language anxiety as "a distinct complex of self-perceptions, beliefs, feelings, and behaviours related to classroom language learning arising from the uniqueness of the language learning process" (1986, p. 128). This type of anxiety is an example of specific anxiety reactions which means that people who fall into this category are anxious only in specific situations and can be differentiated from those who are generally anxious in a variety of situations (see Horwitz et al., 1986). It is therefore a type of situation-specific anxiety that can be distinguished from trait anxiety (the tendency to react in an anxious manner) or other 
forms of state anxiety ${ }^{1}$ (MacIntyre, 1995a; Botes, Dewaele, \& Greiff, 2020). Foreign language anxiety has been reported to have emotional, behavioural, and cognitive effects (MacIntyre, 1995b, p. 246).

Foreign language students experience subjective emotions, psycho-physiological symptoms, and behavioural reactions such as apprehension, worry, forgetfullness, problems with concentration, sweating, palpitations and exhibition of avoidance behaviours (Horwitz et al., 1986). These reactions are exhibited especially during listening and speaking tasks in the foreign language (FL) classroom.

The cognitive effects of foreign language anxiety were captured well by Krashen (1980) who noted that anxiety contributes to an affective filter (i.e., a mental block) which prevents learners from achieving a high level of proficiency in a foreign language (see also Brown, 1973; Muñoz \& Ortega Martín, 2015). Horwitz, Horwitz and Cope (1986) emphasize that it is important for language teachers and students to identify the symptoms and consequences of foreign language anxiety since "the problem of anxiety and the accompanying erroneous beliefs about language learning ... represent serious impediments to the development of second language fluency as well as to performance" (1986, p. 125).

Research on foreign language anxiety is therefore crucial for facilitating successful foreign language learning. However, despite the abundance of studies on FLA, not much research can be found from African universities (see Trang \& Moni, 2015, p. 3). Moreover, what emerges from the literature review is that, whilst a plethora of studies has been conducted on FLA, the examination of the relationship between anxiety and language immersion especially within the unexplored multilingual African cultural contexts is needed. To the best of the author's knowledge, no such studies have been conducted in Ghana. Teimouri, Goetze, and Plonsky's (2019) and Botes

${ }^{1}$ A brief psychological and/or physiological response to a particular undesirable incident.

Legon Journal of the Humanities 32.1 (2021)

Page $\mid 51$ 
et al.'s (2020) recent meta-analysis confirm three factors that merit further attention. There is a pressing need for studies on different learning contexts and target languages (Teimouri et al., 2019) as well as level of multilingualism (Botes et al., 2020). Against this background, the present article provides additional empirical evidence by contributing to the discussion from a hitherto unexplored multilingual African university context. Given that Spanish tends to be the L3 or even L4 of the subjects, the previous language learning experience of the students might offer different insights into the question at hand. Specifically, the author's aim was to:

1. Analyze the anxiety levels among Ghanaian university students of Spanish.

2. Investigate the variance of language anxiety between the different instructional levels.

3. Examine the association between language immersion and anxiety.

4. Examine the association between Spanish FL classroom anxiety and performance.

Foreign Language Anxiety and students' performance

Prior to the mid-1980s, findings concerning anxiety and achievement were predominantly discrepant. The "mixed and confusing" results have been attributed to theoretical and methodological issues such as the divergent measures and definitions used (MacIntyre, 2017). ${ }^{2}$ Although Horwitz, Horwitz and Cope's (1986) introduction of their construct of Foreign Language Anxiety (FLA) and the Foreign Language Classroom Anxiety Scale (FLCAS) have allowed some amount

${ }^{2}$ MacIntyre (2017) categorizes FLA studies in three phases: the confounding phase, the specialized
phase, and the dynamic phase. The confounding phase refers to initial studies on anxiety which, due
to researchers use of general anxiety measures, produced conflicting results regarding the role of
anxiety in language achievement. During the specialized phase, Horwitz et al. (1986) publication
of the FLCAS enabled the reconceptualization of anxiety and comparability across studies within
the context of L2 learning. In the third and final period, the dynamic phase, research focused
on the constant interaction between FLA and other factors over time and in specific contexts. Legon Journal of the Humanities 32.1 (2021)

Page $\mid 52$ 
of uniformity, recent findings continue to produce discrepant results, a reflection of the complex nature of anxiety. For example, even though consistent moderate negative correlations have been found between FLA and academic performance, conflicting results have recently been found on the extent, i.e., large negative correlations, non-significant results, as well as positive correlations have been reported (Botes et al., 2020). FLA has been investigated in relation with other factors such as, perceived competence, self-confidence, language immersion, the learning context and, in recent times, foreign language enjoyment (Dewaele \& Dewaele, 2017; Dewaele et al., 2019).

To begin with, some studies have focused on the progression of anxiety. MacIntyre and Gardner report that beginners experience the most anxiety and advanced students the least. They note that "as experience and proficiency increase, anxiety declines in a fairly consistent manner" (1991, p. 111). Other researchers have provided differing evidence in relation to the differences in levels of anxiety amongst the different proficiency levels. Using the FLCAS, Marcos-Llinás and Garau (2009) examined the effects of language anxiety on course achievement among participants of three proficiency levels of Spanish: beginner, intermediate, and advanced. Their findings suggested that language anxiety did differ across proficiency levels. However, advanced learners showed higher levels of anxiety than beginner and intermediate learners did. Additionally, Onwuegbuzie, Bailey and Daley's (1999) analysis of variance among 210 university students revealed that freshmen and sophomores reported the lowest levels of foreign language anxiety, and that anxiety levels increased linearly as a function of year of study.

Some authors have also concentrated on the relationship between overseas experience and foreign language anxiety and learning (Gardner, Smythe, \& Clément, 1979; Desrochers \& Gardner, 1981; Onwuegbuzie, Bailey, \& Daley 1999). Desrochers and Gardner (1981) examined the correlates and after-effects 
of a four-day trip made by grade eight Anglophone students to a French-speaking community. They found that the excursion students returned with attitudes that were more favourable and had significantly lower levels of anxiety than the students who did not participate in the trip. Furthermore, Gardner et al. (1979) examined the association between attitudinal variables and achievement among Canadian and American adult students of French. They found that the French proficiency of the participants increased after an intensive French summer school programme. On the other hand, their French class anxiety was significantly lower after the programme. Onwuegbuzie et al. (1999) study also investigated factors that predict FLA. Their analysis revealed that prior history of visiting foreign countries and prior high school experience with foreign languages (among other variables) significantly influenced the prediction of FLA.

Furthermore, as mentioned above, several scholars have examined FLA from the perspective of classroom performance (e.g., Phillips, 1992; Aida, 1994; MacIntyre \& Gardner, 1994; Saito \& Samimy, 1996; Bensalem, 2017). Saito and Samimy (1996) investigated the role of language learner anxiety among students studying Japanese at three different instructional levels. They reported that FLA could have a negative impact on Japanese learners' performance. Their study also showed that the influence of FLA becomes more significant as Japanese learners' instructional levels increase. The results of this research corroborate earlier anxiety studies done by Aida (1994). Aida (1994) examined the connection between language anxiety and Japanese language learning. Ninety-six students (56 males and 40 females) completed both a FLCAS and a background questionnaire to measure their anxiety in a first-year Japanese classroom. The author calculated the correlation coefficient between anxiety and course grade using a Pearson productmoment correlation. The results indicated that the higher the students' levels of anxiety, the more likely they were to receive low grades. In addition, they measured the anxiety scores of 
the participants and classified them into either a high anxiety group or a low anxiety group by a median split procedure, based upon each student's total score on the FLCAS. They found that the high anxiety group received significantly lower grades than the low anxiety group. Similarly, Phillips (1992) examined the effects of students' anxiety on classroom achievement using Pearson correlations which were computed between the FLCAS and oral examination grades. The subjects were students enrolled in a French intermediate level course at a private university. The statistical data showed that students who expressed more foreign language anxiety tended to receive lower exam grades than their less anxious classmates.

In relation to the effects of anxiety on achievement, some researchers have examined specific abilities such as oral performance. Using the FLCAS and standardized telephone conversation activity test, Orbeta and San José (2013) conducted a study to examine the link between students' language learning anxieties and their speaking performance. One hundred and fifty (150) college freshmen enrolled in an English course participated in the study. Theirfindings showed there was a correlation between apprehension and the oral performance of the participants in relation to pronunciation, grammar, comprehension, fluency, and vocabulary. However, generally, their study did not show any significant relationship between language learning anxiety and oral performance (Orbeta \& San José, 2013). Park and Lee (2005) also investigated the association between L2 learners' anxiety, self-confidence and oral performance among 132 Korean college students of English. Their anxiety and self-confidence were examined using questionnaires. The factor analysis showed that communication anxiety, criticism anxiety and examination anxiety were the core components of anxiety whereas situational confidence, communication confidence, language potential confidence and language ability confidence were the factors of self-confidence for the participants. Their findings revealed that there were significant effects of anxiety and self-confidence 
on the participants' oral performance since the more confident they were, the higher their oral performances were. The results of the correlation analysis of anxiety/confidence and oral performance revealed that the learners' attitude and interaction (communication strategies and social conversation skills) were more closely related with confidence whereas anxiety was more negatively correlated with participants' oral performance (vocabulary and grammar). Satar and Özdener investigated the use of 2 synchronous computer-mediated communication tools namely, text and voice chat among 30 novice-level secondary school learners of English as a foreign language. Their findings suggest that there was an increment in the speaking proficiency of both experimental groups, whereas the anxiety levels decreased only for the text chat group (Satar \& Özdener, 2008).

Recent meta-analytic investigations confirm the negative association between FLA and academic performance. Teimouri, Goetze, and Plonsky (2019) meta-analysed the research on the relationship between anxiety and L2 achievement. They examined a total of 105 independent samples (N519,933) from 23 countries. According to them, the 216 effect sizes found in the primary studies produced a mean of $\mathrm{r} 52.36$ for the relationship between L2 anxiety and language achievement. Moderator analyses showed that effect sizes differed according to factors such as language achievement measures, educational levels, target languages, and anxiety types. Their study shows that anxiety has a moderate, negative association with achievement (Teimouri et al., 2019). Another meta-analysis carried out by Botes et al. (2020) investigated the connection between FLA using the FLCAS and general academic achievement and four competency-specific outcome scores (reading, writing, listening, and speaking academic achievement). The analysis of the overall sample size of $N=14128$ from 67 articles in a random-effects model using the Pearson correlation coefficients indicated a moderate negative correlation between FLA and all categories of academic achievement (e.g., general academic 
achievement: $r=-.39 ; k=59 ; N=12585)$. The results suggest that individual categories of competence-reading, writing, listening, and speaking academic achievement-are each separately and negatively related to FLA. Furthermore, their meta-analysis indicate that FLA and general academic achievement have a moderately negative relationship and as a result, the higher the levels of learners' FLA, the more probable it is that they will have lower performance scores than their lower-level FLA peers (Botes et al., 2020).

It is important to note that these results which come from correlation analysis could be interpreted in the opposite direction. For example, Tsui's (1996) study demonstrated that high-anxiety students are generally low-performing students. Since students with lower scores tend to be more anxious about everything that relates to the language class, their FLA scores could therefore be a result of their low performance. Indeed, as MacIntyre (1995a) convincingly argued, the association between anxiety, cognition, and behaviour is "recursive or cyclical, where each influences the other" (MacIntyre, 1995a, p. 92). Aptitude can impact anxiety, anxiety can impact performance, and performance can impact anxiety (MacIntyre, 1995a, p. 95). Anxiety can be both a cause and a consequence of poor language achievement (Orbeta \& San José, 2013).

The issue of whether FLA is facilitating, or debilitating has also been debated extensively. Whereas a number of studies have shown that anxiety in the L2 context negatively affects L2 learners' language achievement, as well as their cognitive processing (see Teimouri et al., 2019, p. 364), some scholars emphasize the facilitative aspect of FLA, perceiving it as positive energy (Alpert \& Haber, 1960; see also Bailey, 1983; Oxford, 1999; Liu, 2006; Marcos-Llinás \& Garau, 2009). Bailey's (1983) examination of the diaries she kept while studying French as a foreign language in a US college showed that whereas competitiveness provoked her fear of public failure and anxiety and caused her to withdraw momentarily 
from the study, her anxiety also motivated her to work harder at times. Partial evidence is provided by Liu (2006) from a Chinese University Context. The author examined the impact of anxiety on 20 ESL students' classroom performance as well as the anxiety of their three teachers. The author employed a triangulated method involving the use of the FLCAS, reflective journals, teacher observations, classroom observations and semistructured interviews. The findings showed that anxiety had detrimental effects in EFL classrooms. However, the research also reports the case of one student who believed that anxiety was not debilitative since it made students more self-exigent and motivated better performance. More recently, MarcosLlinás \& Garau (2009) also found that contrary to the findings of previous studies, students with high levels of anxiety did not necessarily exhibit lower course achievement when compared with students with low levels of language anxiety. Moreover, there was a medium level of language anxiety among most participants, with no significant effect on course achievement. They concluded that some amount of language anxiety is probably not as debilitative as it is commonly believed. On the contrary, it could be facilitative in that it may increase learners' motivation and improve their performance (Marcos-Llinás \& Garau, 2009, p. 105).

Nonetheless, the main body of research in FLA supports the view that "anxiety, overall, is negatively associated with L2 achievement" (Teimouri et al., 2019, p. 377) and can be "highly detrimental to the learning process" (MacIntyre, 2017, p. 150). Indeed, negative correlations between language anxiety and achievement have been observed across different target languages including Japanese, Spanish, German, English, and French (see MacIntyre 1995a; Teimouri et al., 2019). Furthermore, evidence is provided by MacIntyre's (2017) recent review of FLA research which shows that it (1) is best theorized only as debilitating, (2) is a cause as well as a consequence of achievement, and (3) has internal as well as social dimensions. 
Actually, other sources of language anxiety such as students' aptitude (Tsui, 1996) and the instructor's teaching styles (Oxford, 1999) have been documented. Another important example of anxiety producing sources which appears to be relevant especially to the present research context is native language skills. Sparks and Ganschow introduced the Linguistic Coding Differences Hypothesis- LCDH (formerly Linguistic Coding Deficit Hypothesis) in 1991 to describe the relationship between one's level of native language skill, aptitude for learning a foreign language and the role of anxiety in foreign language learning. In an empirical study, they examined the relationship between anxiety, native language skills and foreign language aptitude measures among a population of 154 female first year students of a college preparatory high school. Their results indicate that good foreign language learners exhibited significantly stronger native oral and written language skills and foreign language aptitude than poor foreign language learners. Additionally, low-anxious students performed better than highanxious students on measures of native language skills in the phonological/ orthographic domain, on a measure of foreign language aptitude and on end-of-year foreign language grade. Their findings also suggest that there is a positive relationship between low anxiety and strong performance in foreign language classes as well as a negative relationship between high anxiety and weaker performance in foreign language classes. The LCDH has been criticized extensively mainly because it underestimates language anxiety and postulates that anxiety is a consequence rather than a cause of low performance (see MacIntyre, 1995b; for an extensive review, 1995a). However, as MacIntyre observes, it "is not that the LCDH is incorrect" because "native language aptitude determines the parameters within which language learning will occur" and therefore "it is reasonable to hypothesise that these limitations will extend to second languages as well" (MacIntyre, 1995a, p. 96). 
As can be observed from the literature review, there is a considerable amount of divergence in the specifics relating to the levels of anxiety and its association with performance even though there is some uniformity in the broad findings of research on the reality of FLA. Considering this variance in detail, the present paper probes further into the nature and effects of foreign language anxiety in order to confirm and extend previous findings on the subject with evidence from a hitherto unexplored context.

\section{Methods}

The data collection was done in two phases. In this section, we will describe the participants, research setting and procedure.

\section{Research setting}

Ghana is an ethnically heterogeneous country located in West Africa. According to Ethnologue, there are 81 languages spoken in Ghana. Due to inter-ethnic marriages, the majority of Ghanaians are multilingual. Consequently, Ghanaians have one or two local languages as their L1. However, English is the official language, and it is the main medium of instruction from preschool through to the tertiary level. The use of the English language is equally very common within the family domain, especially in homes with parents from different (or even sometimes identical) ethnic backgrounds. English is thus the L2 for the vast majority of Ghanaians. Spanish is subsequently the L3 (or L4) of the Ghanaian participants of this study.

Concerning the research context, the University of Ghana is the oldest and largest Ghanaian university. Usually, the University receives more applications than it can accommodate. Nonetheless, some programmes such as the foreign languages (except for French and Chinese) sometimes receive less applications than allowed by the quota. Hence, the University sometimes assigns courses to students who cannot 
obtain admission to study their preferred courses because of the quota limit. That is, they could be offered the chance to take up admission in the courses with vacancies if they so desire. Additionally, the University uses a "bouquet system" which it introduced in the 2010/2011 academic year. Subjects are categorized into groups or bouquets and students have to choose an entire bouquet (instead of individual subjects) when applying for admission. For instance, a student whose choices are Linguistics, Sociology and Dance would have to choose the bouquet offering Linguistics, Sociology and Russian. Consequently, such a student would get only some of his/her preferred subjects together with other unwanted course(s).

The majority of the participants of this study have no previous contact with the Spanish language before enrolment at the University. However, after their third year of study, some of them travel overseas for a one-year study abroad programme. Five of the best performing students are given a scholarship to Spain and other students who can afford it travel to Spain on selfsponsored programmes. For reasons such as financial constraints or a preference for the French-year abroad programme, ${ }^{3}$ others do not go on the Spanish-year abroad programme. Thirty-six (36) final year students participated in this study. Fifteen (15) of them did not do the year abroad programme whereas 21 did.

Considering the complex multilingual context of the research setting, the author will use the terms own language and new language (Cook, 2010). The first (own language) is "the language which the students already know and through which (if allowed), they can approach the new language" (Cook, 2010, p. xxii). The second term (new language) is "the language being learned" (see Cook, 2010, pp. xxi-xxii). In this study, the own language of the participants is English whereas the new language is Spanish.

${ }^{3}$ Some students combine French and Spanish.

Legon Journal of the Humanities 32.1 (2021) Page $\mid 61$ 


\section{Survey I: Participants and Procedure}

Horwitz et al.'s (1986) Foreign Language Classroom Anxiety Scale (FLCAS) was anonymously administered to Ghanaian University learners of Spanish. The FLCAS has been reported as a valid measure with a consistently high reliability (MacIntyre, 2017). The author used the FLCAS to analyse the anxiety levels among the participants and to investigate the variance of language anxiety between the different instructional levels. The term foreign language used in the original FLCAS was replaced with Spanish language. One-way analysis of variance (ANOVA) (StÄhle \& Svante, 1989) was used in the study to examine whether there exists a significant difference in mean anxiety level between the levels of instruction. According to the ANOVA null hypothesis, if the means are equal against an alternative hypothesis (means are all not equal) and the null hypothesis is rejected, a further test is conducted using the least significant difference (LSD) test (Fisher, 1936) to identify which groups have statistically different population means. The ANOVA was considered appropriate for the present study because it is cognizant of the unequal sample sizes across groups.

Before filling the FLCAS, participants filled a questionnaire on demographic information. The demographic data provided important information on participants, such as their level of multilingualism and self-rating. The participants included first (level 100), second (level 200), third (level 300) and fourth (level 400) year students. In all, 407 students participated in the study. However, given the nature of the information needed for the present study, data from participants who left parts of the questionnaire blank were eliminated. The final number of participants for the study was thus 334 . Of this number, 284 were females, whereas 44 were males. The demographic information on the participants of Survey I is summarised in Table 1. 
Table 1. Demographic data of subjects of Survey I

\begin{tabular}{|c|c|c|c|}
\hline Question & Response & Frequency & Percentage \\
\hline \multirow{5}{*}{ Age } & $15-20$ & 258 & $77.2 \%$ \\
\hline & $21-25$ & 70 & $21.0 \%$ \\
\hline & $26-30$ & 3 & $0.9 \%$ \\
\hline & $31+$ & 1 & $0.3 \%$ \\
\hline & No Response & 2 & $0.6 \%$ \\
\hline \multirow{3}{*}{ Gender } & Female & 284 & $85.0 \%$ \\
\hline & Male & 44 & $13.2 \%$ \\
\hline & No Response & 6 & $1.8 \%$ \\
\hline \multirow{4}{*}{ Nationality } & Ghanaian & 322 & $96.4 \%$ \\
\hline & Non-Ghanaian & 6 & $1.8 \%$ \\
\hline & $\begin{array}{l}\text { Half Ghanaian, } \\
\text { Half Togolese }\end{array}$ & 1 & $0.3 \%$ \\
\hline & No Response & 5 & $1.5 \%$ \\
\hline \multirow{4}{*}{ Level } & 100 & 180 & $53.9 \%$ \\
\hline & 200 & 71 & $21.3 \%$ \\
\hline & 300 & 47 & $14.1 \%$ \\
\hline & 400 & 36 & $10.8 \%$ \\
\hline \multirow{4}{*}{$\begin{array}{l}\text { How would } \\
\text { you describe } \\
\text { your level of } \\
\text { proficiency in } \\
\text { the Spanish } \\
\text { language? }\end{array}$} & Beginner & 180 & $53.9 \%$ \\
\hline & Low intermediate & 101 & $30.2 \%$ \\
\hline & High intermediate & 51 & $15.3 \%$ \\
\hline & Advanced & 2 & $0.6 \%$ \\
\hline \multirow{3}{*}{$\begin{array}{l}\text { Did you choose } \\
\text { Spanish when } \\
\text { applying for } \\
\text { admission to the } \\
\text { University? }\end{array}$} & No & 66 & $19.8 \%$ \\
\hline & Yes & 263 & $78.7 \%$ \\
\hline & No Response & 5 & $1.5 \%$ \\
\hline
\end{tabular}




\begin{tabular}{|c|c|c|c|}
\hline \multirow{5}{*}{$\begin{array}{l}\text { Where have you } \\
\text { had exposure } \\
\text { to the Spanish } \\
\text { language? } \\
\text { (Please tick all } \\
\text { that are relevant) }\end{array}$} & $\begin{array}{l}\text { At home or } \\
\text { elsewhere in the } \\
\text { local community }\end{array}$ & 67 & $20 \%$ \\
\hline & $\begin{array}{l}\text { In a country where } \\
\text { the language is } \\
\text { spoken. }\end{array}$ & 30 & $8.9 \%$ \\
\hline & $\begin{array}{l}\text { In a different } \\
\text { institution }\end{array}$ & 17 & $5 \%$ \\
\hline & $\begin{array}{l}\text { No other } \\
\text { experience other } \\
\text { than previous } \\
\text { courses before this } \\
\text { academic year }\end{array}$ & 216 & $64.6 \%$ \\
\hline & No Response & 20 & $1.9 \%$ \\
\hline
\end{tabular}

The quantitative data for the survey was analysed using SPSS package. Krinis's (2007) classification as well as the median split procedure was used to determine the FLA condition of participants. The survey was done during lecture hours in the first semester of the 2018/2019 academic year.

\section{Survey II: Participants and Procedure}

In Survey II, an analysis was done of the association between students' FLA and their oral performance using end of semester exam scores. Participants were informed about the objectives of the study and their consent was sought in order to access their end of semester grades. To enable the identification of participants for the correlation analysis, the FLCAS was readministered at the end of the first semester. In all, 76 students gave their permission for their grades to be accessed and participated in the survey. However, data from four participants who did not take part in the end of semester oral examinations were eliminated. A summary of the demographic information of the participants of survey II is presented in Table 2. 
Lomotey, B. A./Legon Journal of the Humanities Vol. 32.1 (2021)

Table 2. Demographic data of subjects of Survey II

\begin{tabular}{|c|c|c|c|}
\hline Question & Response & Frequency & Percent \\
\hline \multirow{3}{*}{ Age } & $15-20$ & 48 & 66.7 \\
\hline & $21-25$ & 22 & 30.6 \\
\hline & $26-30$ & 2 & 2.8 \\
\hline \multirow{2}{*}{ Gender } & Female & 65 & 90.3 \\
\hline & Male & 7 & 9.7 \\
\hline \multirow{3}{*}{ Nationality } & Ghanaian & 70 & 97.2 \\
\hline & Japanese & 1 & 1.4 \\
\hline & No Response & 1 & 1.4 \\
\hline \multirow{4}{*}{ Level } & 100 & 40 & 55.6 \\
\hline & 200 & 14 & 19.4 \\
\hline & 300 & 2 & 2.8 \\
\hline & 400 & 16 & 22.2 \\
\hline \multirow{4}{*}{$\begin{array}{l}\text { How would you } \\
\text { describe your level } \\
\text { of proficiency in the } \\
\text { Spanish language? }\end{array}$} & Beginner & 35 & 48.6 \\
\hline & Low intermediate & 18 & 25.0 \\
\hline & High intermediate & 17 & 23.6 \\
\hline & Advanced & 2 & 2.8 \\
\hline \multirow{2}{*}{$\begin{array}{l}\text { Did you choose } \\
\text { Spanish when } \\
\text { applying for } \\
\text { admission to the } \\
\text { University? }\end{array}$} & No & 14 & 19.4 \\
\hline & Yes & 58 & 80.6 \\
\hline \multirow{5}{*}{$\begin{array}{l}\text { Where have you } \\
\text { had exposure to the } \\
\text { Spanish language? } \\
\text { (Please tick all that } \\
\text { are relevant) }\end{array}$} & $\begin{array}{l}\text { At home or elsewhere in } \\
\text { the local community }\end{array}$ & 16 & 22.2 \\
\hline & In a different institution & 2 & 2.8 \\
\hline & $\begin{array}{l}\text { In a country where the } \\
\text { language is spoken. }\end{array}$ & 12 & 16.7 \\
\hline & $\begin{array}{l}\text { No other experience } \\
\text { other than previous } \\
\text { courses before this } \\
\text { academic year }\end{array}$ & 41 & 56.9 \\
\hline & No Response & 5 & 6.9 \\
\hline
\end{tabular}


The statistical data for survey II was analysed using Pearson's correlations which were computed between subjects' FLCAS scores and their oral examination grades. The oral examination consisted of a fifteen-minute interview between individual candidates and two instructors. Students were prepared for the oral examination during the semester with oral lessons which consisted of speaking, writing, reading, and listening drills. The oral examination itself consisted of similar activities under examination conditions. Oral examination scores were considered an appropriate avenue for testing the relationship between anxiety and performance because, firstly, oral activities include aspects of all the other components of a foreign language course (grammar, listening, speaking, reading, critical thinking etc.); and thus give a holistic presentation of students' performance. Secondly, oral tests "have the potential of provoking both test and oral communication anxiety simultaneously in susceptible students" (Horwitz et al., 1986, p. 128). Thirdly, they can reveal the presence of the fear of negative evaluation in vulnerable students. In sum, as Teimouri et al. note, course grades offer an "ecologically valid and practical approach" for exploring effects of anxiety on students'FLlearning (2019, p. 378). The oral examination was evaluated using the general speaking proficiency scale developed by Hughes (2003) consisting of five parts (pronunciation, vocabulary, grammar, fluency, and comprehension).

\section{Results}

The findings from the analysis are presented below.

\section{Overall analysis of students' anxiety level in Spanish language class}

Participants'FLCAS scores were categorized according to Krinis' (2007, cited in Gerencheal, 2016) classification of anxiety levels as follows: very low anxiety $(X=33-82)$, moderately low anxiety $(X=83-89)$, moderate anxiety $(X=90-98)$, moderately 
high anxiety $(X=99-108)$, and high anxiety $(X=109-165)$. The results of the present study showed that with the exception of the level 200 students who had the majority of its sample exhibiting moderately high anxiety $(X=99-108)$, the majority of participants (in each of the remaining groups) fell into the category of high anxiety $(X=109-165)$. For the total sample across the instructional levels, 38.02\% exhibited high anxiety. In all, more than half (199 of 334 [60\%]) of the total sample had FLCAS scores greater than 98; that is, moderately high anxiety. The data is summarised in Table 3.

Table 3. FLA among the various instructional levels according to Krinis' (2007) classification

\begin{tabular}{|c|c|c|c|c|c|}
\hline LEVEL & $\begin{array}{l}\text { Very } \\
\text { low } \\
\text { anxiety } \\
(X=33- \\
82)\end{array}$ & $\begin{array}{l}\text { Moderately } \\
\text { low anxiety } \\
(\mathrm{X}=83-89)\end{array}$ & $\begin{array}{l}\text { Moderate } \\
\text { anxiety } \\
(X=90-98)\end{array}$ & $\begin{array}{l}\text { Moderately } \\
\text { high anxiety } \\
(X=99-108)\end{array}$ & $\begin{array}{l}\text { High } \\
\text { anxiety } \\
(X=109 \text { - } \\
165)\end{array}$ \\
\hline 100 & $\begin{array}{l}24 \\
13.33 \%\end{array}$ & $\begin{array}{l}17 \\
9.44 \%\end{array}$ & $\begin{array}{l}27 \\
15.00 \%\end{array}$ & $\begin{array}{l}29 \\
16.11 \%\end{array}$ & $\begin{array}{l}83 \\
46.11 \%\end{array}$ \\
\hline 200 & $\begin{array}{l}15 \\
21.13 \%\end{array}$ & $\begin{array}{l}9 \\
12.68 \%\end{array}$ & $\begin{array}{l}7 \\
9.86 \% \\
\end{array}$ & $\begin{array}{l}22 \\
30.99 \%\end{array}$ & $\begin{array}{l}18 \\
25.35 \%\end{array}$ \\
\hline 300 & $\begin{array}{l}5 \\
10.64 \%\end{array}$ & $\begin{array}{l}4 \\
8.51 \%\end{array}$ & $\begin{array}{l}9 \\
19.15 \%\end{array}$ & $\begin{array}{l}13 \\
27.66 \%\end{array}$ & $\begin{array}{l}16 \\
34.04 \%\end{array}$ \\
\hline 400 & $\begin{array}{l}8 \\
22.22 \% \\
\end{array}$ & $\begin{array}{l}3 \\
8.33 \% \\
\end{array}$ & $\begin{array}{l}7 \\
19.44 \% \\
\end{array}$ & $\begin{array}{l}8 \\
22.22 \% \\
\end{array}$ & $\begin{array}{l}10 \\
27.78 \% \\
\end{array}$ \\
\hline TOTAL & $\begin{array}{l}52 \\
15.57 \%\end{array}$ & $\begin{array}{l}33 \\
9.88 \%\end{array}$ & $\begin{array}{l}50 \\
14.97 \%\end{array}$ & $\begin{array}{l}72 \\
21.56 \%\end{array}$ & $\begin{array}{l}127 \\
38.02 \%\end{array}$ \\
\hline
\end{tabular}

Differences of language anxiety levels according to level of instruction

The mean score of the first-year students was 3.17, that of the second-year students was 2.98, the third-year students had 3.12 and the final year students had 2.99. The mean FLCAS score for the first-year students (104.69) was the highest recorded 
followed by the third-year students with a mean of 103.06. Next was the fourth-year students with a mean of 98.64 and then lastly, the second-year students had the lowest mean FLCAS score (98.41). Table 4 shows the overall anxiety condition across the various instructional levels.

Table 4. Spanish language anxiety levels across the various instructional levels

\begin{tabular}{|l|l|l|l|}
\hline Level & $\begin{array}{l}\text { Possible } \\
\text { Range Min- } \\
\text { Max }\end{array}$ & Mean & Std Deviation \\
\hline \multirow{2}{*}{100} & $47-159$ & 104.69 & 20.01 \\
\cline { 2 - 4 } & $1.42-4.82$ & 3.17 & 0.61 \\
\hline \multirow{2}{*}{200} & $61-136$ & 98.41 & 17.37 \\
\cline { 2 - 4 } & $1.85-4.12$ & 2.98 & 0.53 \\
\hline \multirow{2}{*}{300} & $69-140$ & 103.06 & 16.55 \\
\cline { 2 - 4 } & $2.09-4.24$ & 3.12 & 0.50 \\
\hline \multirow{2}{*}{400} & $66-141$ & 98.64 & 18.53 \\
\cline { 2 - 4 } & $2-4.27$ & 2.99 & 0.56 \\
\hline
\end{tabular}

Before conducting the analysis of variance (ANOVA) to examine the significance of the difference in the mean anxiety levels, a graphical representation of the anxiety levels using the box plot was produced. The results (Figure 1) showed that the mean anxiety levels are relatively the same for all levels. 


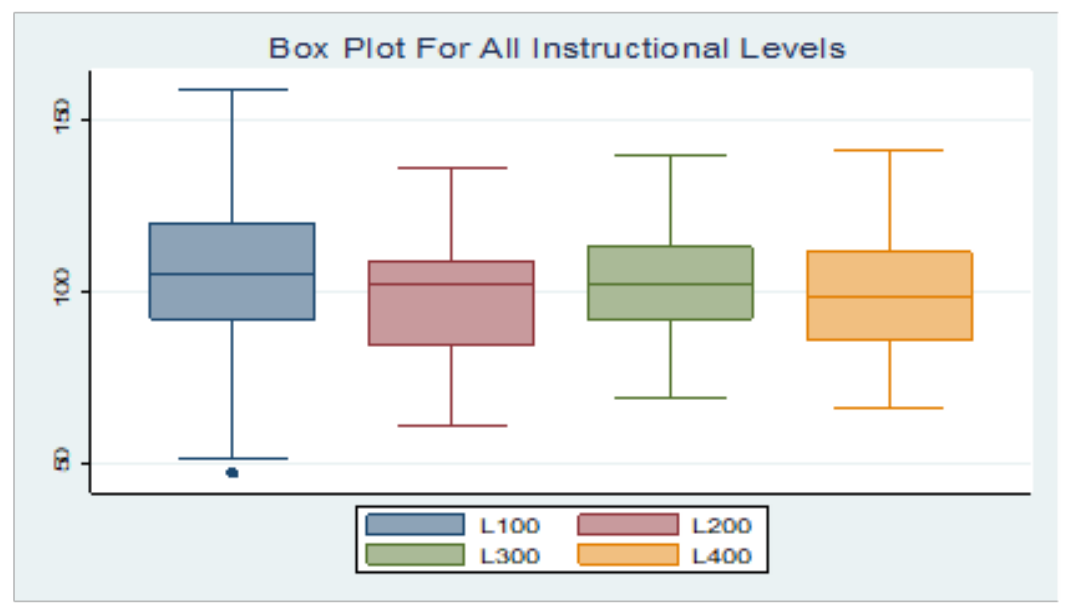

Figure 1. Box Plot for anxiety levels across the instruction levels

Additionally, the ANOVA revealed that no significant difference exists in the mean anxiety level across the levels of instruction - the $p$-value $=0.064$ was greater than $5 \%$. The findings thus showed that anxiety levels were the same across the instructional levels. Since the null hypothesis of the ANOVA was not rejected, the author did not proceed to the LSD test. Table 5 presents the ANOVA results.

Table 5. Differences of language anxiety levels according to level of instruction

\section{Source of}

\begin{tabular}{lcrcccc}
\multicolumn{1}{c}{ Variation } & SS & df & MS & F & P-value & F crit \\
\hline Between Groups & 2606.845 & 3 & 868.9483 & 2.443394 & 0.064031 & 2.631975 \\
Within Groups & 117358.5 & 330 & 355.6317 & & &
\end{tabular}


The association between Spanish classroom anxiety and performance

To examine the effects of specific components of anxiety on the Spanish achievement test, the researcher divided the scores according to the three related performance anxieties identified by Horwitz et al. (1986) as well as general anxiety: (1) communication apprehension; (2) fear of negative evaluation; (3) test anxiety; and (4) general anxiety of Spanish classes. The correlation coefficients were then calculated with their corresponding $\mathrm{p}$-values for three out of the four groups (i.e., levels 100, 200 and 400) for each variable. For the level 300 students, due to the small sample size, the researchers applied the method of observation before reaching a conclusion.

The results of the Pearson correlation analysis indicated that the specific variables of anxiety and the participants' achievement test had a negative correlation in all cases. The various variables all had a debilitative effect on the achievement test for all the levels. Apart from communication apprehension, fear of negative evaluation and test anxiety for the second-year students and also communication apprehension for the fourthyearstudents, the remaining components all had significant effects from the $1 \%$ through the $5 \%$ significance levels. General anxiety had a higher effect on the level $100(-0.604, \mathrm{p}=0.000<0.01)$ and level $200(-0.728, \mathrm{p}=0.003<0.05)$ students' achievement test. For the level 400 students, test anxiety $(-0.610, p=0.012<0.05)$ had the greatest effect on their achievement test. 
Table 6. The association between FLA and achievement among the various instructional levels

\begin{tabular}{|c|c|c|c|}
\hline $\begin{array}{l}\text { Variable Of } \\
\text { Anxiety }\end{array}$ & Level & \begin{tabular}{|l|} 
Correlation \\
Coeffecient
\end{tabular} & P-Value \\
\hline \multirow{3}{*}{$\begin{array}{l}\text { Communication } \\
\text { Apprehension }\end{array}$} & 100 & $-0.433 * *$ & 0.005 \\
\hline & 200 & -0.478 & 0.084 \\
\hline & 400 & -0.427 & 0.099 \\
\hline \multirow[t]{3}{*}{$\begin{array}{l}\text { Fear of Negative } \\
\text { Evaluation }\end{array}$} & 100 & $-0.387^{*}$ & 0.014 \\
\hline & 200 & -0.458 & 0.100 \\
\hline & 400 & $-0.608 *$ & 0.013 \\
\hline \multirow[t]{3}{*}{ Test Anxiety } & 100 & $-0.381 *$ & 0.015 \\
\hline & 200 & -0.189 & 0.518 \\
\hline & 400 & $-0.610^{*}$ & 0.012 \\
\hline \multirow[t]{3}{*}{$\begin{array}{l}\text { General Anxiety } \\
\text { of Spanish } \\
\text { Classes }\end{array}$} & 100 & $-0.604 * *$ & 0.000 \\
\hline & 200 & $-0.728 * *$ & 0.003 \\
\hline & 400 & $-0.516^{*}$ & 0.041 \\
\hline \multirow[t]{3}{*}{$\begin{array}{l}\text { Overall Spanish } \\
\text { Classroom } \\
\text { Anxiety }\end{array}$} & 100 & $-0.523 * *$ & 0.001 \\
\hline & 200 & $-0.572 *$ & 0.033 \\
\hline & 400 & $-0.590 *$ & 0.016 \\
\hline
\end{tabular}

The results of the above Pearson correlation analysis reveal that first, second, and final year students had a significant, moderately strong, and negative correlation between their overall FLCAS scores and achievement test scores. Regarding the level 300 students, the participant with the highest anxiety score 
had the least achievement score (see Table 8). This implies the possible existence of a negative correlation for the participants in that category as well. Additionally, the data demonstrates that the effect of the overall Spanish classroom anxiety on the test score of a final year student was relatively greater than that of a second-year student. The anxiety level had a greater effect on the achievement test of a second-year student than it did on that of a first-year student. The significant negative correlation between Spanish classroom anxiety and achievement test found in this study confirms previous findings on the debilitative effects of FLA on performance. The findings also suggest that the negative effects of FLA on performance increases as instructional levels increase.

\section{Language immersion and anxiety}

To measure the effect of language immersion on anxiety levels, final year students (L400) were divided into two groups - year abroad and non-year abroad students. The table below shows a frequency distribution of the different classifications of anxiety levels between non-year abroad students and year abroad students.

Table 7. Anxiety levels among non-year abroad and year abroad students

\begin{tabular}{lcccc}
\hline \multirow{2}{*}{ Anxiety Level } & \multicolumn{2}{c}{ Non-Year Abroad } & \multicolumn{2}{c}{ Year Abroad } \\
\cline { 2 - 5 } & Frequency & Percent & Frequency & Percent \\
\hline Very Low & 1 & $7 \%$ & 7 & $33 \%$ \\
Moderately Low & 2 & $13 \%$ & 1 & $5 \%$ \\
Moderate & 5 & $33 \%$ & 2 & $10 \%$ \\
Moderately High & 3 & $20 \%$ & 5 & $24 \%$ \\
High & 4 & $27 \%$ & 6 & $29 \%$ \\
Total & 15 & & 21 & \\
\hline
\end{tabular}

The difference in mean method was used to measure the effect of language immersion on language anxiety. Before proceeding to the difference in mean test, an examination was 
first made for equal variance. The null hypothesis ( $\mathrm{p}$-value $=$ $0.14>(5 \%))$ was not rejected in the test of equal variance and this confirmed that variances were equal. The null hypothesis that there is no significant difference in mean anxiety levels was then tested against the alternate hypothesis that there exists a significant difference in mean anxiety levels. Given the results of the equality of variance test, the difference in mean test was conducted assuming equal variance. The p-value $(0.65)$ of the difference in mean test was greater than the 5\% significant level. The results therefore showed that no significant differences exist between the mean anxiety levels of non-year abroad and year abroad students.

\section{Discussion}

The findings of this study lend empirical support to previous research which reported the anxiety-provoking potential of language learning, and its subsequent effects on student performance. Additionally, a significant variance in the language anxiety levels of the different instructional levels was also observed. The results however contradict the findings of MacIntyre and Gardner in which anxiety was found to decline "in a fairly consistent manner as experience and proficiency increased" (1991, p. 111). Surprisingly, the findings also contradict previous studies that suggest that language immersion influenced anxiety levels.

The broad divergence in the findings of existing studies can probably be attributed to the research contexts. In the present context, some factors that could have influenced the anxiety levels of the learners include admission procedures, class size, nature of the learning environment, lack of previous exposure to the FL, and the year-abroad programme. It seems very plausible that class size could be a significant contributory factor to learners' anxiety levels. Undoubtedly, factors such as time pressure when called upon to answer a question in a large class could lead to fear of negative evaluation and communication 
anxiety. Moreover, almost a quarter of the participants did not opt to study the language (see section on Research setting). This could be because of unfavourable attitudes towards (or lack of knowledge about the value of) the language and could lead to a lack of motivation which could in turn affect the efficiency of learning leading to anxiety.

Concerning the variance in levels of FLA across instructional levels, the findings can be interpreted as a result of the following factors. First-year students had high levels of anxiety probably because for them the Spanish language and culture is a new experience. ${ }^{4}$ They logically are anxious as they are uncertain what to expect. They transition to the more relaxed state of fascination by the second year ${ }^{5}$ when they feel more settled in the university environment, are relatively more comfortable with the new language being learnt, and believe they know "what to expect". Furthermore, in the context of the research setting of this study, the third year is the period in which students switch from purely language (grammar and oral) and civilization classes to higher levels of learning the new language (i.e., Spanish literature). As a result, they could find themselves once again, in a phase of anxiety. Some learners could adjust by the final year. Not only would they have enhanced their language learning skills, but they would also have improved their communication skills in the new language considerably, thereby reducing their anxiety levels.

In relation to the correlation between language anxiety and achievement, the results of the Pearson correlation analysis shows that students' Spanish classroom anxiety and their classroom achievement had negative association in all groups. It was observed that the debilitative effect of anxiety was however

${ }^{4}$ As shown in Table 1, 64.6\% of the participants had no exposure to the Spanish language before enrolling into the Spanish program at the University.

5 At the University of Ghana, students moving from L100 to L200 have an option to drop one of the three courses they took at L100. As such, L200 students have the choice to either continue studying Spanish or drop it. Consequently, the class size drops significantly after L100. 
most significant on the achievement test of the final year students. This supports the findings of Saito and Samimy (1996) who report that the influence of foreign language anxiety becomes more significant as learners' instructional levels increase. This can probably be attributed to the fact that final year students are aware that they are about to graduate and are anxious to successfully pass their final year examinations.

The originality of the current study lies in the fresh evidence it provides from a multilingual context. A considerable number of the available research on FLA was carried out among monolingual students who had a common L1 as the own language. In this study however, the participants were multilinguals who did not all share a common L1. Rather, they shared a common L2 (their own language) which was used as the medium of instruction alongside the new language. This study therefore differs from the more classical L2 contexts in that the new language was the L3 or L4 (and even in some cases L5 etc.) of the subjects. Although the present study does not explicitly test the relationship between native language skills, foreign language aptitude and FLA, the results of this study could also reflect the influence of students' native language skills on their language learning aptitude and FLA as demonstrated by Ganschow and Sparks' (1996) study. It should be emphasised that I do not argue that their anxiety is mainly a result of native language aptitude and coding problems. Rather, I identify it as one of the possible contributory factors. On the one hand, as explained earlier, English is the L2 of most Ghanaians and the majority of them are more literate in it than in their native languages. It is also the language they use for thought processing (see Lomotey, 2020) which suggests that they are more advanced users of English than their native languages (see Atkinson, 1987). On the other hand, Ghanaians may not always use the English language correctly, given that they learn the language both formally (e.g., in school) and informally (through socialization and day to day activities like watching local television programmes). 
Indeed, Owu-Ewie (2006) points out that the language policy of the Ghanaian educational system makes Ghanaian children imbalanced bilinguals who master neither the Ghanaian language nor English (see also Bodomo, 1996; Adika, 2012). As argued by Ganschow and Sparks (1996) and other researchers in second language acquisition (e.g., MacIntyre, 1995a; OwuEwie, 2006) the development of proficiency in the new language is directly impacted by the level of aptitude in the own language. There could be an association between FLA, native language skills and foreign language aptitude in that "performance on the FLCAS ... may reflect students' levels of native language skill and foreign language aptitude" (Ganschow \& Sparks, 1996, p. 208). Consequently, in line with MacIntyre (1995a), I postulate that native language aptitude does have an important association with anxiety; they are complementary rather than exclusive factors and this could be an explanation for the trend observed in the current study. The data from the present complex linguistic research setting may be interpreted as additional empirical support for the relationship between own language skills and FLA because, as argued by Ganschow and Sparks, the influence of native language skills on FLA can be "indirectly measured" (1996, p. 208) by performance on the FLCAS.

Future research efforts could directly examine the impact of students' native language skills on FLA and foreign language learning in multilingual contexts. Additionally, the use of correlation coefficients is a limitation to the present study as it does not infer causality, and this could be addressed in future research.

\section{Conclusion, pedagogical implications, and future directions}

It is crucial that FL teachers acknowledge the presence of FLA in the FL learning process and implement measures for its reduction and management. FLA does have detrimental effects on foreign language learning. The present study provides additional evidence for future meta-analysis of FLA research on 
Spanish as a FL especially since existing meta-analytic studies have focused on work on ESL. This paper could therefore add to the collection of articles for the meta-analysis of studies on the teaching of Spanish as a FL. Such research has important pedagogical implications, as it can help teachers create the optimal emotional climate in their classrooms (Dewaele et al., 2019).

The pedagogical implication of the present study, complementing previous research, is that although the effect varies according to the level of instruction, all three components of the FLCAS (communication apprehension, fear of negative evaluation, and test anxiety) as well as general anxiety are significant within this context. Some ways FLA can be mitigated are by explaining to students that it is not necessary to comprehend every word uttered in the classroom and that also, error-making is a natural occurrence in language learning (in fact, even native speakers of a language can and do make linguistic errors in their language). Teachers' usage of tension reducing techniques in error-correction (e.g., embedded correction) will also play a significant role in reducing classroom anxiety. By so doing, the FL learning classroom will be a less portentous and formidable environment. Students' anxiety can thus be reduced while improving their risk-taking and willingness to practise the new language. Indeed, as shown by recent findings in foreign language enjoyment, positive emotions can undo the repercussions of negative emotional arousal (MacIntyre \& Gregersen, 2012). Teachers who are not overly strict, but rather, are friendly, humorous, encouraging, and considerate will help their learners relax in the classroom. As argued by Krashen (1982), this could spark interest, provide low-anxiety environments, bolster learners' self-esteem and ultimately, bring learners' filters down.

Finally, students should be educated and encouraged to carry out an introspective evaluation to find out if and how FLA affects them. Learners can then make conscious efforts to 
overcome these triggers and engage in self-help habits that will reduce their FLA. Alternatively (or additionally), depending on how affected they are by FLA, they could also seek advice from their course advisors or their university's Learning Skills Centre on how to manage FLA. In sum, taking these measures would facilitate positive beliefs, feelings, and behaviours towards the new language. Moreover, it would help to ameliorate poor language learning habits, reduce the levels of anxiety, and improve students' performance. Ultimately, it would also have the long-term effect of facilitating student recruitment and retention.

\section{Acknowledgement}

This research was supported by the University of Ghana Building a New Generation of Academics in Africa (BANGAAfrica) Project with funding from the Carnegie Corporation of New York. The funding source had no involvement in the undertaking of the study. I would like to thank Dr. Anani Lotsi and Mr. Reginald Acquah for their assistance with the data analysis. 


\section{References}

Adika, G. S. K. (2012). English in Ghana: growth, tensions, and trends. International Journal of Language, Translation and Intercultural Communication, (1), 151-166.

Aida, Y. (1994). Examination of Horwitz, Horwitz, and Cope's Construct of Foreign Language Anxiety: The Case of Students of Japanese. The Modern Language Journal, 78(2), 155-168.

Alpert, R., \& R. N. Haber. (1960). Anxiety in Academic Achievement Situations. Journal of Abnormal and Social Psychology, 61(2), 207-215.

Atkinson, D. (1987). The Mother Tongue in the Classroom: A Neglected Resource? ELT Journal, 41(4), 241-247.

Bailey, K. M. (1983). Competitiveness and Anxiety in Adult Second Language Learning: Looking at and Through the Diary Studies. In

H. W. Seliger, \& M. Long (Eds.), Classroom Oriented Research in Second Language Acquisition (pp. 67-102). Rowley, MA: Newbury House.

Bensalem, E. (2017). Foreign Language Learning Anxiety: The Case of Trilinguals. Arab World English Journal Volume, 8(1), 234-249.

Botes, E., J. M. Dewaele \& S. Greiff. (2020). The Foreign Language Classroom Anxiety Scale and Academic Achievement: An Overview of the Prevailing Literature and a Meta-Analysis. Journal for the Psychology of Language Learning, 2(1), 26-56.

Bodomo, A. B. (1996). On Language and Development in Africa: The Case of Ghana. Nordic Journal of African Studies, 5(2), 31-51.

Brown, H. D. (1973). Affective Variables in Second Language Acquisition. Language Learning, 23(2), 231-244.

Cook, G. (2010). Translation in Language Teaching: An Argument for Reassessment. Oxford: Oxford University Press.

Dewaele, J.-M. \& L. Dewaele. (2017). The Dynamic Interactions in Foreign Language Classroom Anxiety and Foreign Language Enjoyment of Pupils Aged 12 to 18. A Pseudo-Longitudinal Investigation. Journal of the European Second Language Association, 1(1), 12 22.

Dewaele, J. M., A. F. Magdalena \& K. Saito. (2019). The Effect of Perception of Teacher Characteristics on Spanish EFL Learners' Anxiety and Enjoyment. The Modern Language Journal, 103(2), 412-427.

Desrochers, A. \& R. Gardner. (1981). Second-Language Acquisition: An Investigation of a Bicultural Excursion Experience. Quebec: International Centre for Research on Bilingualism.

Fisher, R. A. (1936). Design of Experiments. Br Med J, 1(3923), 554-554.

Ganschow, L. \& R. Sparks. (1996). Anxiety about Foreign Language Learning among High School Women. The Modern Language Journal, 80(2), 199-212. 
Gardner, R. C., P. C. Smythe \& R. Clément. (1979). Intensive Second Language Study in a Bicultural Milieu: An Investigation of Attitudes, Motivation and Language Proficiency. Language Learning, 29(2), 305-320.

Gerencheal, B. (2016). Gender Differences in Foreign Language Anxiety at an Ethiopian University: Mizan-Tepi University Third Year English Major Students in Focus. Online Submission, 1(1), $1-16$.

Horwitz, E. K., M. B.Horwitz \& J. Cope. (1986). Foreign Language Classroom Anxiety. The Modern Language Journal, 70(2), 125132.

Krashen, S. D. (1980). The Input Hypothesis. In J. E. Alatis (Ed.), Current Issues in Bilingual Education: Georgetown University Round Table on Languages and Linguistics (pp. 168-180). Washington: Georgetown Univ. Press.

Hughes, A. (2003). Testing for Language Teachers. Cambridge: Cambridge University Press.

Liu, M. (2006). Anxiety in EFL Classrooms: Causes and Consequences. ESL Reporter, 39(1), 13-32.

Lomotey, B. A. (2020). Revisiting the Classic Debate on Language Choice in the FL Classroom: Current Perspectives from a Ghanaian University. RASK - International Journal of Language and Communication, 51, 17-38.

MacIntyre, P. D. \& R. Gardner. (1991). Methods and Results in the Study of Anxiety and Language Learning: A Review of the Literature. Language Learning, 41(1), 85-117.

MacIntyre, P. D. \& R. Gardner. (1994). The Subtle Effects of Language Anxiety on Cognitive Processing in the Second Language. Language Learning, 44(2), 283-305.

MacIntyre, P. D. (1995a). How Does Anxiety Affect Second Language Learning? A Reply to Sparks and Ganschow. The Modern Language Journal, 79(1), 90-99.

MacIntyre, P. D. (1995b). On Seeing the Forest and the Trees: A Rejoinder to Sparks and Ganschow. The Modern Language Journal, 79(2), 245-248.

MacIntyre, P. D., \& Gregersen, T. (2012). Emotions that facilitate language learning: The positive-broadening power of the imagination. Studies in Second Language Learning and Teaching, 2, 193-213. MacIntyre, P. D. (2017). An Overview of Language Anxiety Research and Trends in its Development. In M. D. C. Gkonou, \& J. Dewaele (Eds.), New Insights into Language Anxiety (pp. 11-30). Bristol: Multilingual Matters.

Marcos-Llinás, M. \& M. J. Garau. (2009). Effects of Language Anxiety on Three Proficiency-Level Courses of Spanish as a Foreign Language. Foreign Language Annals, 42(1), 94-111. 
Muñoz, A. \& J. L. Ortega Martín. (2015). Affective Variables in Second Language Acquisition and their Effect on the Spanish Academic Context. Revista de Lenguas para Fines Especificos, 21(1), 41-66.

Orbeta, E. D. \& A. E. San José. (2013). Apprehension in Language Learning Anxiety as Significant Correlate of Oral Performance in English of College Freshmen. International Association of Multidisciplinary Research, 5, 155-164.

Onwuegbuzie, A. J., P. Bailey \& C. E. Daley. (1999). Factors Associated with Foreign Language Anxiety. Applied Psycholinguistics, 20(2), 217-239.

Owu-Ewie, C. (2006). The Language Policy of Education in Ghana: A Critical Look at the English-Only Language Policy of Education. In J. Mugane, J. P. Hutchison, \& D. A. Worman (Eds.), Selected Proceedings of the 35th Annual Conference on African Linguistics (pp. 76-85). Somerville, MA: Cascadi.

Oxford, R. (1999). Anxiety and the Language Learner: New Insights. In J. Arnold (Ed.), Affect in Language Learning (pp. 260-278). Cambridge, UK: Cambridge University Press.

Park, H. \& A. R. Lee. (2005). L2 Learners' Anxiety, Self-Confidence and Oral Performance. In Proceedings of the 10th Conference of Pan-Pacific Association of Applied Linguistics (pp. 107-208). Edinburgh University.

Phillips, E. M. (1992). The Effects of Language Anxiety on Students' Oral Test Performance and Attitudes. The Modern Language Journal, 6(1), 14-26.

Saito, Y. \& K. K. Samimy. (1996). Foreign Language Anxiety and Language Performance: A Study of Learner Anxiety in Beginning, Intermediate, and Advanced-Level College Students of Japanese. Foreign Language Annals, 29(2), 239-252.

Satar, H. M. \& N. Özdener. (2008). The Effects of Synchronous CMC on Speaking Proficiency and Anxiety: Text Versus Voice Chat. The Modern Language Journal, 92(4), 595-613.

StÄhle, L., \& W. Svante. (1989). Analysis of variance (ANOVA).

Chemometrics and Intelligent Laboratory Systems, 6(4), 256-272.

Teimouri, Y., J. Goetze \& L. Plonsky. (2019). Second Language Anxiety and Achievement: A Meta-analysis. Studies in Second Language Acquisition, 41(2), 363-387.

Trang, T. T. \& K. Moni. (2015). Management of Foreign Language Anxiety: Insiders' Awareness and Experiences. Cogent Education, 2(1), 1-20.

Tsui, A. (1996). Reticence and Anxiety in Second Language Learning. In K. M. Bailey, \& D. Nunan (Eds.), Voices from the Language Classroom (pp. 145-167). Cambridge, United Kingdom: Cambridge University Press. 